This article was downloaded by: [Temple University Libraries]

On: 22 April 2015, At: 06:28

Publisher: Routledge

Informa Ltd Registered in England and Wales Registered Number: 1072954

Registered office: Mortimer House, 37-41 Mortimer Street, London W1T

3J H, UK

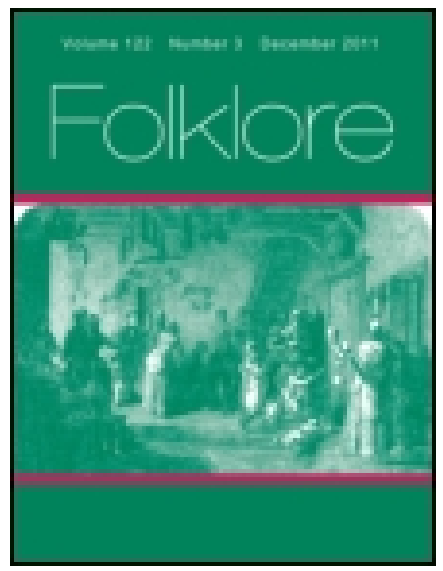

\title{
Folklore
}

Publication details, including instructions for authors and subscription information:

http:// www. tandfonline.com/loi/ rfol20

\section{Mr. Stuart-Glennie on the Origins of Matriarchy}

Alfred Nutt \& J oseph J acobs

Published online: 14 Feb 2012.

To cite this article: Alfred Nutt \& J oseph J acobs (1891) Mr. Stuart-Glennie on the Origins of Matriarchy, Folklore, 2:3, 367-372, DOI: 10.1080/0015587X.1891.9720070

To link to this article: http:// dx. doi.org/ 10.1080/0015587X.1891.9720070

\section{PLEASE SCROLL DOWN FOR ARTICLE}

Taylor \& Francis makes every effort to ensure the accuracy of all the information (the "Content") contained in the publications on our platform. However, Taylor \& Francis, our agents, and our licensors make no representations or warranties whatsoever as to the accuracy, completeness, or suitability for any purpose of the Content. Any opinions and views expressed in this publication are the opinions and views of the authors, and are not the views of or endorsed by Taylor \& Francis. The accuracy of the Content should not be relied upon and should be independently verified with primary sources of information. Taylor and Francis shall not be liable for any losses, actions, claims, proceedings, demands, costs, expenses, damages, and other liabilities whatsoever or howsoever caused arising directly or indirectly in connection with, in relation to or arising out of the use of the Content.

This article may be used for research, teaching, and private study purposes. Any substantial or systematic reproduction, redistribution, reselling, loan, sub-licensing, systematic supply, or distribution in any form to anyone is 
expressly forbidden. Terms $\&$ Conditions of access and use can be found at http://www.tandfonline.com/page/terms-and-conditions 


\section{MR. STUART-GLENNIE ON THE ORIGINS OF MATRIARCHY.}

$\mathrm{O}$ the second volume of Miss Garnett's Women of
Turkey and their Folk-lore ("Jewish and Moslem Women"), Mr. Stuart-Glennie has added a study on the "Origins of Matriarchy", in which he treats this puzzling institution as an exemplification of his general theory of the origins of civilisation, and seeks support for his contention in the folk-tale. His argument thus has especial interest for folk-lorists, and, pending a detailed notice of the work to appear shortly in FOLK-LORE, I wish to call attention to the importance of the points raised by Mr. Stuart-Glennie.

As is well known, Mr. Stuart-Glennie seeks the determining impetus towards our present state of civilisation in the relations between primitive white races (whom he designates Archaian) and coloured races of an altogether inferior mental and moral strain. These relation swere invariably ones of subordination on the part of the lower races. But this subordination varied in degree, and was at times and in places consistent with marriage between women of the higher and men of the lower race. In these cases the wife would retain such political, social, and personal rights as we find in matriarchal communities. To verify the hypothesis, Mr. Stuart-Glennie analyses the folk-lore relating to marriage of the peoples living around the eastern Mediterranean, under three heads: (I) Family usages; (2) marriage sanctions; (3) wedding ceremonies. Historically, as he points out, the patriarchal family has been the dominant type in this region for over 2,000 years ; yet, in spite of this, the folk-lore presents marked matriarchal features. Thus, the chief sanctions of the patriarchal 
marriage are race-identity, contract, assent ; the chief ceremony is the propitiation of ancestors. But of matriarchal marriage the chief sanctions are non-kinship, capture, consent; the chief ceremony is propitiation of the powers of nature. Numerous are the still surviving customs which can best be explained by the matriarchal conception of society. But it is in folk-poesy, even more than in folkcustom, that Mr. Stuart-Glennie seeks for matriarchal survivals, and it is especially in the Swan-Maiden group of tales that he finds them. Here he polemises against Mr. Hartland in what seems to me an unnecessary way, the polemic having little bearing upon the main contention. But I will leave Mr. Hartland to defend his views, as he is so well able to do. It is urged, then, that in the Swan-Maid group the father is either unmentioned or subordinate, the wife or mother is supreme, the family and not the father consent to or refuse the marriage, the hero is, as a rule, a fatherless child. Again, the Swan-Maid is always described in terms that differentiate her racially from the hero; she is only to be won by achievement, whether capture of herself, killing of her guardian, or performance of tasks; finally, the tale nearly always includes submission of the husband to a taboo, the breaking of which entails for him the loss of the wife.

This brief recapitulation of Mr. Stuart-Glennie's points will show of what importance his argument is to all who essay to explain the facts of folk-lore. I may at once express my opinion that little would be needed to bring Mr. Stuart-Glennie's and Mr. Hartland's explanations into line with each other. They impress me as being complementary rather than antagonistic. Both writers, in effect, treat the stories as evidence of a bygone social, intellectual, and moral state, which state dates back to a hoary antiquity. That in interpreting the survivals from such a remote period divergences should arise is but natural. But if it is once agreed that the stories do contain traces of a past state of humanity, correct inter- 
pretation can only be a matter of time and study. But what if the stories contain no such traces, or at least only traces of a state of affairs which obtained amongst a small section of humanity, and if the development of the stories has not been conditioned by custom, but by the simple desire to make the tale varied and exciting? How are we, then, to discriminate between what is the record or the symbol of custom or of belief, and what is simply the play of free fancy? Here, again, the fundamental question of folk-lore crops. Is this lore in the main the outcome of the social and mental phases through which a race has passed, or is it a miscellaneous and meaningless collection of borrowings?

It is evident that any historical theory of progress which fits the facts of folk-lore into the general scheme favours the first of these views. In so far I hold the anthropological school may claim Mr. Stuart-Glennie as their partisan, however much divergence there be on questions of method and nomenclature, even of historical evolution at large. The main point is that there has been evolution, and that folk-lore testifies thereto.

I do not think that Mr. Stuart-Glennie's working out of his views is as yet sufficiently exhaustive to allow of satisfactory criticism. It has the most ingenious and taking look; but acceptance must be deferred until not only the Swan-Maid group of tales has been analysed in greater detail, but until other groups of folk-tales have shown themselves susceptible of a like interpretation. It is greatly to be hoped that some workers at folk-tales will apply Mr. Stuart-Glennie's principles and methods. The examination of the märchen corpus is too formidable a task for one man.

As regards Mr. Stuart-Glennie's general theory of matriarchalism, I would urge that it does not derive support from recent history. When of late higher races have come in contact with lower ones, marriage between women of the former and men of the latter has seldom obtained. voL. 11 . 
True, one of the conditions of matriarchalism obtains in such instances of race-contact-the practical fatherlessness of many children of the women belonging to the lower race. But, as Mr. Stuart-Glennie most rightly insists, the problem of matriarchalism lies not in uncertain, or rather undeclared paternity, but in the supremacy of the woman. Mr. Stuart-Glennie's explanation of this problem is fascinating, but is it true? In any case it deserves most serious attention.

Alfred NutT.

SINCE I became acquainted with Mr. Stuart-Glennie's ingenious views of the origin of civilisation, I have been especially interested in it. We that are content if we reach what we consider to be some approximation of the truth in one small department of some limited section of a definite division of the knowable, cannot but admire the confidence and the vigour with which $\mathrm{Mr}$. Stuart-Glennie settles the affairs of humanity in the epochs before history. There is something Titanic about the whole of his researches that compels admiration for the exploit. Personally I have a sneaking regard for a theory of civilisation which makes it one huge example of the Borrowing-Theory, to which I have, most unscientifically, I fear, pinned my partiality, so that I am ready to welcome it even where no facts exist on which to base our judgment. But where no facts, or few facts, or still unverified facts exist, we have no choice but to revert to hypothesis-provided we have the courage of Mr. Stuart-Glennie, and are content to fall with our hypothesis when facts prove unkind and refuse to fall into the pigeon-holes we have prepared for them.

There is one main principle of human nature which tells strongly for Mr. Glennie's hypothesis to which I desire on the present occasion to draw attention. Civilisation is a matter of culture; culture, again, is a matter of leisure. Now, under early economic conditions (are they much 
different nowadays?) leisure is only possible with slavelabour. Again, slave-labour as an organised institution is only possible on a large scale when there is a strong and marked difference of race between slave-owner and slave. Hence it becomes a priori possible, and even likely, that when the elements of civilisation arose-a dignified architecture, a norm of manners and ceremonial-there must have existed a marked difference of race, with consequent slave-labour. All this tells for Mr. Stuart-Glennie.

But whether matriarchy arose as a result of this, with connubium between female slave-owners and their slaves, depends on evidence, and evidence is sadly wanting both in ancient and modern times in this direction. Indeed, so far as it goes, it tends otherwards : the status of the child follows that of the mother, it is true, in all archaic eyot systems; but how rarely, when status differs between the parents, is that of the mother the higher! Just at present, too, with Dr. Westermarck's book before us, need we hypothesise about matriarchy as a theory when matriarchy as a fact is on its trial?

Again, as to Mr. Glennie's views on the Swan-Maiden story, is it not somewhat embarrassing for him that the interest and sympathy of the audience are always invoked for the husband who loses his eerie wife? Qud man, is he not regarded as the superior of the fickle, mysterious maid that leaves him for the break of a taboo? And what evidence, again, have we that the Swan-Maiden type of story has lasted on from the times of the White Archaian Race, whose earliest visible beginnings on the banks of the Nile are anterior to 14,700 years ago, whenabouts the Zodiac was invented?

I have thought it right to express my doubts about these more recent developments of Mr. Stuart-Glennie's views, as they might cause attention to be detracted from the more promising part of his hypothesis, the probabilities that civilisation had its origin in some dominant race, and was parsed on from that race to others. Half the battle is 
won in a scientific problem when we know where to look for a solution: all the rest is but detail work. . If Mr. Stuart-Glennie is not looking just at present at the right objects, I think there can be little doubt he is looking in the right direction.

JOSEPH JACOBS. 